\title{
The criteria for evaluation and selection the best tender applied by the authorities in Poland and selected EU countries
}

\author{
Beata Grzyl ${ }^{1,{ }^{*}}$, Magdalena Apollo ${ }^{1}$, Emilia Miszewska-Urbańska ${ }^{1}$, and Adam Kristowski ${ }^{1}$ \\ ${ }^{1}$ Gdańsk University of Technology, Faculty of Civil and Environmental Engineering, Narutowicza \\ 11/12, 80-233 Gdansk, Poland
}

\begin{abstract}
The aim of the regulation in EU countries concerning public procurement is to ensure efficient spending of funds by evaluating and choosing the most advantageous offer. The aim of the conducted research is to determine the extent the Polish contracting entities benefit from the possibility of broad selection of various criteria for tender evaluation. On the basis of the analysis of 500 notices on work procedures conducted in the third quarter of 2016 - the third quarter of 2017 in open and restricted tenders in Poland and 500 tenders in open and restricted proceedings in five selected EU countries, the authors compared and classified of applied the practical criteria to evaluate and select the best offer. In order to collect the information presented in the article, the authors applied the documentary method using domestic and foreign literature regarding the subject and official publications.
\end{abstract}

\section{Introduction}

One of the EU's key priorities under the Europe 2020 strategy is sustainable development, including to support a competitive, resource-efficient and environmentally-friendly economy. An important objective of EU public procurement legislation is to provide contractors with the ability to compete effectively for public contracts in other Member Countries and to increase the efficiency of public spending. The purpose of the Directives $[1,2]$ is the simplification of procurement procedures, improving the procedure implementation, to enhance the sustainable development and the economy innovativeness and to increase involvement of small and medium-sized entities in the public procurement market $[3,4]$. The changes in EU legislation aim to achieve a right relationship between the three complementary elements: the environment, the society and the economy $[5,6]$. The measures carried out in this area are related to the monitoring of the mineral resource usage, carbon dioxide emission, waste management and economic phenomena (e.g. supporting the entities by means of renewable energy sources) and social (social security and economic stability of the population) [7]. The coordination of activities in the above areas is aimed at developing a compromise between social needs, technology development and rational use of environmental resources $[8,9]$. One of the methods of working towards a sustainable

${ }^{*}$ Corresponding author: beata.grzyl@pg.edu.pl 
development strategy is to implement the rules governing the above relationships, including the award of public procurement and the application of additional criteria to select the best offer.

\section{The types of award criteria}

The contracting authority is not restricted in setting the criteria for tender evaluation, however, each criterion must refer to the subject of the contract.

Exemplary criteria for evaluating tenders and awarding for work contracts ("build and design" and "build" options) may include [10]:

1. The cost criteria, which include: the offer price, the amount of the discount granted to the contracting authority, the gross work rate, the life cycle costs of the facility $[11,12,13]$, including operating costs, terms of payment (e.g. payment schedule, payment terms),

2. The objective criteria, which may include: deadline for realization of the contract subject, the quality determined by the percentage share of the contractor's self-realization of the contract and the technical parameters of materials applied for the execution of works [14, 15], the methodology, functionality, warranty terms, the organization, the social and environmental aspects $[16,17,18]$.

\section{The analysis of selection criteria for the best offer applied in selected EU countries}

\subsection{The analysis of award criteria applied by awarding entities in Poland}

The obligation to implement the Directive by Poland [1] imposed an obligation to amend the Public Procurement Law from 22 June 2016 [19]. The Directive introduced a number of changes in terms of cost and non-cost award criteria.

In order to determine the type and number of award criteria applied by Polish contracting authorities and the selection of the most favourable tender for construction works, the authors analyzed 500 proceedings of the value above the EU thresholds, conducted through open and restricted tendering in the third quarter of 2016 - the third quarter of 2017. The information has based on the notices contained in the Public Procurement Information Bulletin of the Public Procurement Office [20] regarding the construction works, implemented in the "build" and "design and build" system.

Table 1. The criteria for evaluation and selection of the best offer applied by the awarding entities in Poland. Source: own study based on [20].

\begin{tabular}{|l|c|c|}
\hline $\begin{array}{c}\text { The applied criterion of evaluation } \\
\text { and selection of the best offer }\end{array}$ & $\begin{array}{c}\text { The mean weight of a } \\
\text { given criterion [\%] }\end{array}$ & $\begin{array}{c}\text { The percentage of proceedings } \\
\text { involving a given criterion [\%] }\end{array}$ \\
\hline Price & 58,6 & 100 \\
\hline Implementation deadline & 45,5 & 24,6 \\
\hline The period of guarantee/warranty & 43,3 & 48,8 \\
\hline $\begin{array}{l}\text { Quality, functionality, technical } \\
\text { parameters }\end{array}$ & 32,4 & 25,3 \\
\hline Knowledge, experience, etc. & 26,8 & 20,6 \\
\hline Terms and conditions of payment & 23,1 & 20,2 \\
\hline
\end{tabular}

The main objective of the amendment of the Public Procurement Law [19] is to strengthen the non-price criteria for tender evaluation. The introduced changes, may result 
in seen broader (compared to the previous years) application of non-price criteria by awarding entities such as the deadline and guarantee period (Table 1). Attention is paid to the importance of other non-price criteria and considering them important enough by the authorities. In every fourth procedure, the criteria of awarding the contract is the quality of execution of the works and the functionality of the proposed solutions, in every fifth - the knowledge and experience of persons directed to the performance of the contract and the terms of payment. The results of the analysis of selected investigations also indicate that the criteria applied to evaluate and select the most advantageous offer do not include criteria dealing with the social, environmental or innovation aspects [21, 22].

In Poland and in other EU Member Countries, the same Directive [1] is in force, however, in assessing and selecting the best offer, each country may choose slightly different criteria. In order to determine the nature and number of award criteria applied by awarding entities from five selected EU countries, the authors analyzed 500 selected open and restricted construction procedures from the third quarter 2016 - to the third quarter 2017, whose values rise above the EU thresholds.

\subsection{The analysis of award criteria applied by awarding entities in Sweden}

The results of the analysis indicate that in Sweden the contracting authorities take into account the price criterion (in each analyzed case), but also the qualifications and experience of the persons participating in the performance of the contract, the way of planning the implementation of the investment and the environmental aspects (Table 2). In $83.1 \%$ of cases conducted in Sweden one of the decisive selection criteria is the experience of persons performing the order, and the mean weight of this criterion is $34.2 \%$ (the maximum weight in the analyzed proceedings was $60 \%$ ). The attention is also drawn to the fact that almost half of the analyzed cases use the environmental criterion. The average weight of this criterion is $15.3 \%$. This means that in most cases this is a complementary criterion. Similarly looks the criteria of "completion date of the order subject". It occurs in $33.5 \%$ of the analyzed cases, its overage weight is $13.1 \%$. The criterion "social aspects" is applied in average in every 5 cases.

Table 2. The criteria for evaluation and selection of the best offer applied by the contracting authorities in Sweden. Source: own study based on [23].

\begin{tabular}{|l|c|c|}
\hline $\begin{array}{c}\text { The applied criterion of evaluation and } \\
\text { selection of the best offer }\end{array}$ & $\begin{array}{c}\text { The mean weight of a } \\
\text { given criterion [\%] }\end{array}$ & $\begin{array}{c}\text { The percentage of } \\
\text { proceedings involving } \\
\text { a given criterion [\%] }\end{array}$ \\
\hline Price & 51,5 & 100 \\
\hline Professional qualifications, experience & 34,2 & 83,1 \\
\hline Organization, planning, consistency of tasks & 31,6 & 21,5 \\
\hline Social aspects & 20,4 & 20,1 \\
\hline Environmental aspects & 15,3 & 45,2 \\
\hline Implementation deadline & 13,1 & 33,5 \\
\hline Architectural approach (e.g. using BIM) & 11,9 & 15,4 \\
\hline
\end{tabular}

\subsection{The analysis of award criteria applied by contracting authorities in Spain}

While choosing the best offer, the Spanish contracting authorities mainly use the criteria of price, technical capacity, financial and professional capacity of the entity (average weight: $34.9 \%$ ) and warranty period (average weight: $11.0 \%$ ). In Spain, the price criterion is normally used in each of the analyzed proceedings. Its average weight is $58.8 \%$. There are a number of criteria applied in Spanish procurement (Table 3). The most frequently used 
criteria for choosing the best offer are: time of realization, environmental and social aspects, quality, functionality, efficiency of solutions, quality of applied materials. In every 4 proceedings the best offer is chosen based on the criteria "completion date", "quality of applied solutions and materials" and "organization, planning and coherence of tasks, including application of BIM technology in planning and execution of investment". In Spanish proceedings social and environmental criteria also appear. Their average weight is about $12 \%$, which in most cases does not determine the choice.

Table 3. The criteria for evaluation and selection of the best offer applied by the contracting authorities in Spain. Source: own study based on [23].

\begin{tabular}{|l|c|c|}
\hline $\begin{array}{c}\text { The applied criterion of evaluation and } \\
\text { selection of the best offer }\end{array}$ & $\begin{array}{c}\text { The mean weight of } \\
\text { a given criterion [\%] }\end{array}$ & $\begin{array}{c}\text { The percentage of } \\
\text { proceedings involving } \\
\text { a given criterion [\%] }\end{array}$ \\
\hline Price & 58,8 & 100 \\
\hline Financial and professional capacity & 34,9 & 46,2 \\
\hline Implementation deadline & 24,2 & 23,1 \\
\hline Social aspects & 13,6 & 32,8 \\
\hline Organization, planning (the use of BIM) & 13,4 & 24,8 \\
\hline Quality, functionality, technical parameters & 12,3 & 39,4 \\
\hline Environmental aspects & 11,3 & 33,3 \\
\hline The period of guarantee & 11,0 & 42,4 \\
\hline Quality of applied solutions and materials & 9,7 & 24,9 \\
\hline
\end{tabular}

\subsection{The analysis of award criteria applied by contracting authorities in France}

Table 4. The criteria for evaluating and selecting the best offer applied by the contracting authorities in France. Source: own study based on [23].

\begin{tabular}{|l|c|c|}
\hline \multicolumn{1}{|c|}{$\begin{array}{c}\text { The applied criterion of evaluation and } \\
\text { selection of the best offer }\end{array}$} & $\begin{array}{c}\text { The mean weight of } \\
\text { a given criterion [\%] }\end{array}$ & $\begin{array}{c}\text { The percentage of } \\
\text { proceedings involving } \\
\text { a given criterion [\%] }\end{array}$ \\
\hline Price & 52,3 & 100 \\
\hline Financial and professional capacity & 41,6 & 81,3 \\
\hline The method of execution & 21,4 & 5,4 \\
\hline Implementation deadline & 18,2 & 14,6 \\
\hline The cost analysis & 17,8 & 5,9 \\
\hline Environmental aspects & 15,7 & 21,3 \\
\hline Quality, functionality, technical parameters & 15,3 & 4,8 \\
\hline Organization, planning, consistency of tasks & 14,7 & 12,6 \\
\hline Professional qualifications, experience & 13,1 & 11,8 \\
\hline Quality of the applied materials & 12,2 & 7,3 \\
\hline The architectural approach (e.g. using BIM) & 12,1 & 1,8 \\
\hline
\end{tabular}

The price criterion occurs in each of the analyzed French proceedings. The average weight is $52.3 \%$, which means that it does not determine in any case the result of the selection. An important, frequently applied criterion deals with technical, financial and professional capacity of the contractor. It reports on the financial capacity of the company, takes into account technical and human resources involved in the implementation of the contract subject, describes the principles of safety and effectiveness of activities undertaken during the investment implementation. Under this criterion, the technical solutions applied for the execution of the order, as well as environmental requirements, may be taken into account. This criterion is found in $81.3 \%$ of analyzed orders with an average weight of $41.6 \%$. Both 
implementation method criterion with an average weight of $21.4 \%$ and a "cost analysis" criterion with an average weight of $18.8 \%$ are also worth mentioning. In $21.3 \%$ of the investigated procedures, the contracting entities take into consideration the environmental aspects while assessing and selecting the most advantageous tender. The average weight of this criterion is not too high $-15.7 \%$. The results of the analysis indicate that the selection of the most advantageous offer also applies to other criteria of smaller importance (Table 4) e.g. BIM [24].

\subsection{The analysis of award criteria applied by awarding entities in Germany}

The most advantageous offer in Germany is chosen primarily on the basis of price and the quality criteria. The price criterion is a standard in every German case with an average weight of $54.8 \%$. The quality criterion is applied in every second procedure in Germany. Another important criterion for selection is organization and task planning (average weight: $36.2 \%$ ). The weight of the following criteria "completion date" and "environmental aspects" $(24.8 \%, 23.5 \%)$, indicate that in some cases they may be decisive in choosing the best offer. In almost every case, risk management criterion occurs (Table 5). The innovation criterion occurs in individual proceedings only.

Table 5. Evaluation and selection criteria of the best offer applied by the contracting authorities in Germany. Source: own study based on [23].

\begin{tabular}{|l|c|c|}
\hline $\begin{array}{c}\text { The applied criterion of evaluation and } \\
\text { selection of the best offer }\end{array}$ & $\begin{array}{c}\text { The mean weight of } \\
\text { a given criterion [\%] }\end{array}$ & $\begin{array}{c}\text { The percentage of } \\
\text { proceedings involving } \\
\text { a given criterion [\%] }\end{array}$ \\
\hline Price & 54,8 & 100 \\
\hline Quality, technical parameters, use of BIM & 41,2 & 48,3 \\
\hline Organization, task planning & 36,2 & 26,9 \\
\hline Implementation deadline & 24,8 & 14,2 \\
\hline Environmental aspects & 23,5 & 28,5 \\
\hline Risk management & 21,7 & 19,4 \\
\hline Guarantee period & 19,0 & 10,2 \\
\hline Experience & 17,9 & 17,3 \\
\hline Innovation & 7,5 & 3,9 \\
\hline
\end{tabular}

\subsection{The analysis of award criteria applied by awarding entities in Czech Republic}

Table 6. The criteria for evaluation and selection of the best offer applied by the contracting authorities in the Czech Republic. Source: own study based on [23].

\begin{tabular}{|l|c|c|}
\hline $\begin{array}{c}\text { The applied criterion of evaluation and } \\
\text { selection of the best offer }\end{array}$ & $\begin{array}{c}\text { The mean weight of a } \\
\text { given criterion [\%] }\end{array}$ & $\begin{array}{c}\text { The percentage of } \\
\text { proceedings involving } \\
\text { a given criterion [\%] }\end{array}$ \\
\hline Price & 75,3 & 100 \\
\hline Terms and conditions of warranty & 27,4 & 38,9 \\
\hline Implementation deadline & 25,2 & 65,4 \\
\hline Experience & 18,1 & 26,3 \\
\hline Quality, functionality, technical parameters & 16,9 & 7,6 \\
\hline Environmental aspects & 15,3 & 5,7 \\
\hline Organization, task planning & 9,8 & 3,5 \\
\hline
\end{tabular}


In Czech Republic, when choosing the most advantageous offer, three criteria are most important: price, guarantee and the date of realization of the order subject. The average weight of the price criterion is as much as $75.3 \%$. Other criteria ("experience", "quality, functionality", "technical specifications") are complementary only, in most cases they do not prejudge the choice of the offer. The criteria for evaluation and selection of the most favorable environmental aspects and organization and task planning are applied in individual cases (Table 6).

\section{Conclusions}

The analysis of selected procedures concerning the execution of construction works in the "build" and "design and build "system in the aspect of evaluation criteria and selection of the best offer applied in Poland and selected EU countries justifies the formulation of the following conclusions and statements.

1. The Directive $[1,2]$ applicable in EU countries, promotes the application of numerous non-price criteria for tender evaluation. The results of the analysis indicate that Polish and Czech contracting authorities do not apply this possibility. In tendering procedures conducted in these countries, one or two non-price criteria (term of performance, guarantee period) are most frequent, but due to their low weight, in most cases they do not act strongly on the final evaluation and selection of the best offer. The price plays a decisive role. The results show that contracting authorities from Sweden, Spain, France and Germany are more likely to use different criteria for evaluating and choosing the most advantageous tender - they generally use 4 to 5 criteria. In many cases, the criterion of decisive importance, besides price is "experience", "innovation" and "environmental aspects". Comparing the most commonly applied criteria in Poland and France, many differences can be seen (Fig.1).

In French orders, the practical criteria such as guarantee or social aspects do not are observed. Technical, financial and professional ability, a method and time of execution of the contract play an important role. Contrary to Polish, in the French public procurement, the cost of life cycle analysis is taken into account while choosing the offer. In the case of French and Swedish proceedings, the criterion of the extension of the warranty period does not apply, although in Poland it occurs in every second procedure. In Sweden, contracting authorities highly point out the qualifications and experience of staff, organization and task planning, and social and environmental aspects. In the Swedish and French cases, the criteria for job planning, work organization are applied. In Poland such criteria are practically not used (Fig.2).

2. The Directive [1] grants Member Countries the freedom to regulate these matters under national legislation. This means that the Member Countries themselves decide whether the price criterion in the contracts awarded in these countries is limited. Despite the significant reduction of the price criterion for construction works in Poland (up to 60\%), criteria of a qualitative, environmental, social, innovative nature have not been widely applied yet.

3. In many cases where the evaluation and selection of the best offer is based on two criteria only, the weight of the first criterion is so large that the second criterion is insignificant. In the case of proceedings to take a greater number of criteria into account in tender evaluation a greater competition occurs. Thus the contractor selects "the most economically advantageous tender", to bring about a high work quality and additionally takes into the consideration the prosocial and environmental aspects of the investment. On the other hand, the contractor, who fulfills all additional non-price requirements of the ordering party may win the proceeding despite offering higher prices than the competitors. 


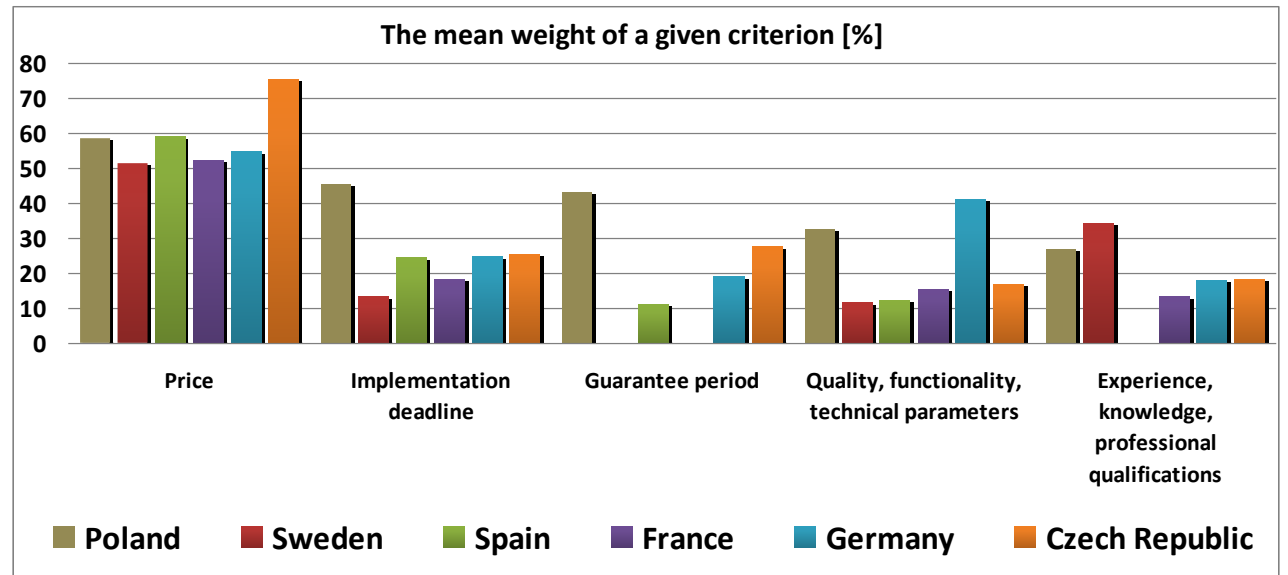

Fig. 1. Used criterion. Source: own study based on [23].

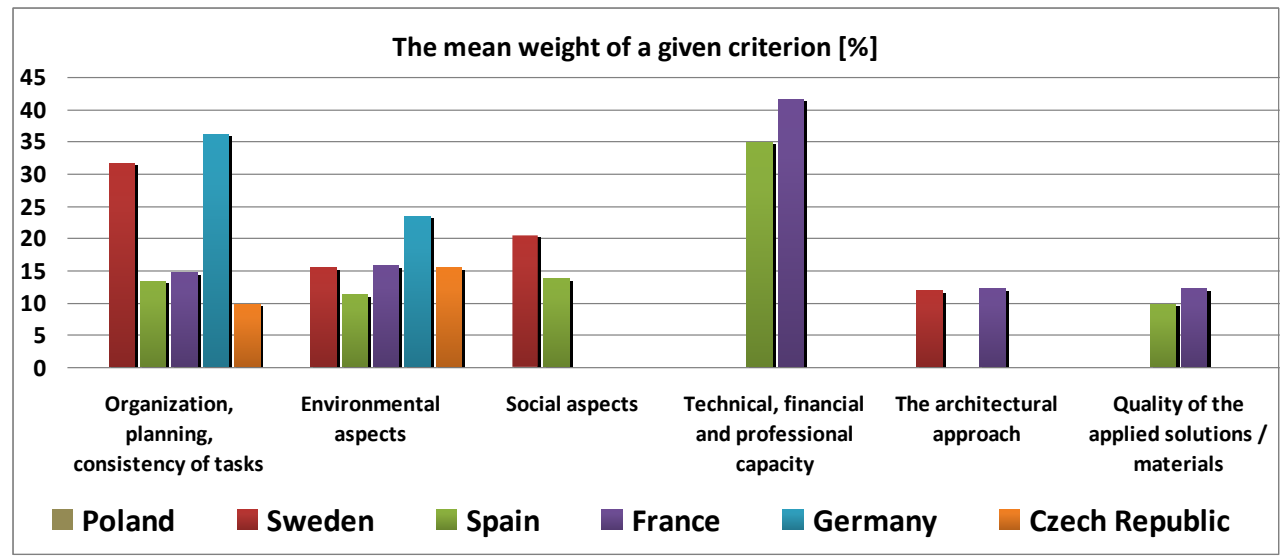

Fig. 2. Unused criterion. Source: own study based on [23].

4. The application of the price as the decisive criterion for the selection of the offer has its advantages (e.g. speed, simple application, safety of the contracting authority, low cost of preparation and conducting of the proceedings) but also disadvantages (e.g. no possibility to award specific features of the order, low operating costs, modern technological solutions). The application of price and other criteria of significant importance gives numerous benefits, e.g. it contributes to increase the efficiency of spending public funds like the ability to precisely match the selection of the offer to the specific needs of the contracting entity, a better preparation of the description of the subject of the order and a precise definition of the essential features of the product, the promotion of its desirable qualities e.g. innovation, quality, limited environmental impact. In practice, however, it raises a lot of difficulties for the procuring entity, e.g. increasing the cost and effort of preparing and carrying out the procedure, resulting in a more complex and longer procedure for evaluating submitted tenders, sometimes involving experts to evaluate proposed solutions, improves the possibility of incorrect definition of evaluation criteria and questioning them by tenderers.

\section{References}


1. Dyrektywa Parlamentu Europejskiego i Rady 2014/24/UE z dnia 26 lutego 2014 r. w sprawie zamówień publicznych.

2. Dyrektywa Parlamentu Europejskiego i Rady 2014/25/UE z dnia 26 lutego 2014 r. w sprawie udzielania zamówień przez podmioty działające w sektorach gospodarki wodnej, energetyki, transportu i usług pocztowych.

3. D. Łapacz, International Business and Global Economy, Zamówienia publiczne w UEanaliza porównawcza procedur $w$ wybranych państwach członkowskich, 34, 67-77, (2015)

4. B. Wieczerzyńska, Rocznik Administracji Publicznej, Efektywność zamówień publicznych $w$ wymiarze prawnym, ekonomicznym i spotecznym, 2, 558-570, (2016)

5. J. Szymonek, Zrównoważone zamówienia publiczne w Polsce: możliwości, bariery, strategie, (2017)

6. E. Dziawgo, Prace Naukowe Uniwersytetu Ekonomicznego we Wrocławiu, Realizacja strategii „Europa 2020” w krajach Unii Europejskiej, 478, (2017)

7. M. Wojcińska, D. Wojciński, Kontrola Państwowa, Klauzule społeczne w zamówieniach publicznych-szanse na upowszechnienie ważnych rozwiązań, 62 (2(373)), 113-126 (2017)

8. B. Grzyl, E. Miszewska-Urbańska, M. Apollo, E3S Web Conf., 17, (2017)

9. M. Apollo, E. Miszewska-Urbańska, Adv. Sci. Technol. Res. J., 9(28), 68-74, (2015)

10. F. Łapecki, G. Wicik, 2016. Zamówienia publiczne po nowemu - poradnik dla małych i średnich przedsiębiorców, PARP, Warszawa (2016)

11. E. Plebankiewicz, K. Zima, D. Wieczorek, Technical Transactions, Quantification of the risk addition in life cycle cost of a building object, 5, 35-45, (2017)

12. M. Juszczyk, A. Leśniak, K. Zima, Z. Nauk./WSOWL im. gen. T. Kościuszki, Selected issues of bills of quantities in construction works in Poland, 1, 189-200, (2017)

13. Leśniak, K. Zima, Sustainability, 10, 5 (2018)

14. M. Kurpińska, T. Ferenc, ITM Web Conf., 15, (2017)

15. M. Pszczoła, J. Judycki, D. Ryś, Transportation Research Procedia, 14, 738-747, (2016)

16. M. Łojko, Studia Ekonomiczne, Klauzule społeczne jako instrument wsparcia rozwoju ekonomii społecznej w procesie zamówień publicznych, 326, 108-121, (2017)

17. M. Łysakowski, Magazyn Autostrady, Pozacenowe kryteria oceny ofert w przetargach na budowę dróg, 5, 142-146, (2018)

18. M. Maksimiuk, Magazyn Autostrady, Przetargi na oświetlenie drogowe-nowe kryteria oceny ofert, 1-2, 36-38, (2017)

19. Tekst jednolity ustawy Prawo zamówień publicznych, poz. 1579 (2017)

20. Biuletyn Informacji Publicznej UZP BIP, 2017, https://www.bip.gov.pl

21. Z. Walczak, A. Szymczak-Graczyk, Przegl. Bud., BIM jako narzędzie przyszłości w projektowaniu i rewitalizacji obiektów budowlanych, 88, 20-26, (2017).

22. K. Zima Procedia Engineering, 208, 203-210 (2017)

23. The supplement to the Official Journal of the EU., 2017, http://www.ted.europa.eu

24. B. Grzyl, E. Miszewska-Urbańska, M. Apollo M., Procedia Engineering, 196, 10261033, (2017) 